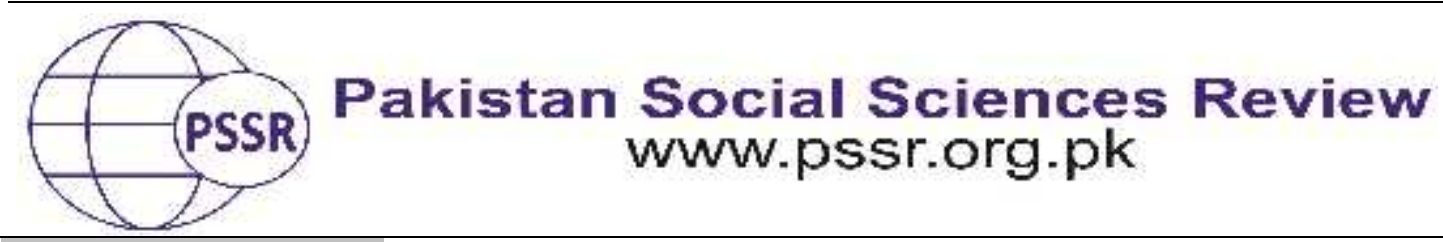

RESEARCH PAPER

\title{
Changing Cultural Patterns with Reference to Modernity: Facts from Public Sector Universities in Punjab, Pakistan
}

Sidra Noreen ${ }^{* 1}$ Dr. Izhar Ahmad Khan ${ }^{2}$ Dr. Farkhanada Anjum ${ }^{3}$

1. Ph. D Scholar, Department of Rural Sociology University of Agriculture Faisalabad, Punjab, Pakistan

2. Associate Professor, Department of Rural Sociology, University of Agriculture Faisalabad Punjab, Pakistan

3. Assistant Professor, Department of Rural Sociology, University of agriculture Faisalabad Punjab, Pakistan

PAPER INFO

Received:

January 09, 2021

Accepted:

March 01, 2021

Online:

March 15, 2021

Keywords:

Cultural

Hegemony,

Globalization,

Modernity,

Modernization

Westernization

*Corresponding

Author

Sidrasiyan@yma

il.com

\section{ABSTRACT}

Culture has a deep influence on all aspects of human behavior. The impact of culture may be delicate or marked, direct or leaning, stable or temporary. It is so tangled with all aspects of human survival that it is frequently difficult to define how and in which ways its influence is manifested. Culture patterns are occurring due to educated youth as drastic social transformation under Western influence. The role of modernity in culture among youth is bringing several changes. Therefore, the current study is helpful for evaluating the effects of Modernity among educated youth of universities in Punjab, Pakistan. The study hypothesized that modernity has a positive relationship with cultural change. For achieving the objectives and testing hypothesis, researcher used quantitative researcher approach and conducted survey among the students using cross sectional survey design. Two stage probability sampling technique was used and a total of 420 students were selected using stratified sampling technique and simple random sampling technique respectively. However, both modernity and cultural change had been found higher among younger. It is recommended to take necessary steps to increase the benefits of modernity and cultural change and decrease negative consequences of modernity.

\section{Introduction}

Modernity is the product of globalization (Orzeata, 2013). This implies that globalization is giving birth to contemporary values and practices. This adoption of these contemporary values and practices (contemporary cultural values) which are different from previous values and practices (traditional cultural values) are commonly termed modern values and practices and this process is termed 
modernity (Arnett, 2005; Orzeata, 2013). Modernity is the outcome of interaction between people and systems of different cultures in the worlds. In other words, modernity is the outcome of interconnectedness of people, knowledge, values and practices across the borders in the world (Belk, 2017). This modernity led by globalization affected each and every country in the world regardless of their socioeconomic status. However, developing countries got more affected by these modern forces (Tenhunen,2018).

Modernity is found affecting population and its dynamics, social values, economic development, access to media both electronic and social media, information technology and socio-economic development. In other words, modernity is altering each and every aspect of human life from material to nonmaterial culture (Godart et al. 2015). However, modernity is affecting rapidly to material culture. In addition, material culture is changing across the world because of global forces which are operating from every corner of the world and also reaching to every corner to the world (Gray \& Purdy, 2018). For example, the use of highly modern and technologically oriented machinery and equipment are increasing even in third world countries. In addition, the uses of modern weapons are also increasing even in orthodox communities which are against modernized Knowles and equipment (Hong \& Cheon, 2017).

Currently $64 \%$ of the nation is younger than 30 and 29\% of Pakistanis are between the ages of 15 and 29 (an age group we refer to as youth). There are more young people in Pakistan now and it is predicted that it will continue to grow by at least 2050 (shakeel,2018). This study focuses on the changing lifestyles of urban youth in Pakistani society. It seeks to explore how life-styles are changing despite rise in religiosity, religious radicalism, acts of terror, violence, personal insecurity and vigilante justice? To have deeper understanding of changing life styles, this study focuses on three areas; fashion design, electronic media advertisements and the emerging cafe/restaurant culture. Are these changes confined to elite classes or cut across class lines? The focus of the study is urban Pakistan.Youth comprise approximately $32^{\circ}$ o (aged 15-29) of Pakistan's population and there are varying interpretations about their orientation, outlook and worldview.

\section{Literature Review}

This study is focused on answering the question that why cultural patterns are changing. The hypothesis for this aim is framed that it is impact of modernity which is changing cultural patterns. Modernity is the way to thinking and living as expressed in Western society (Mignolo, 2011). The term modernity is not a cross cutting concept but it is very wide concept which include social, cultural and intellectual dimensions in it (Feola, 2015). These social, cultural and intellectual dimensions are the practices of European and Western society which are now regarded as blue print for socio-economic development (LeVine \& White, 2017). Modernity provides alternations and replacement of traditional and indigenous cultural values in the form of Western cultural values and practices (Bashkow, 2017). 
The concept of modernity and cultural change is not new in sociological discourse. However, in most of the studies, modernity is studied at macro level. For example globalization is inserting new trends in the fields of education, health and economics. In addition, they were also of the views that globalization is also increasing overall socio-economic development in the country (Persson, 2012).

Globalization which leads to modernity inserts new trends as well as new technologies in developing societies (Amin, 2014). Developing societies are also now practicing new technology in the field of education, health and economy (Beck, 2018). In addition, diversity and respect for global values is also found higher in developing societies now a day. This implies that modernity is closely linked to globalization (Charron, 2016). There are many researchers who had studied cultural globalization which is the adoption of globalized trends and techniques. This adoption of global culture is actually modernity (Persson, 2012).

Modernity is studied in term of modern values and the values which started in Europe especially during nineteenth and twentieth century (Childs, 2016). Both the cultural values of Eastern and Western part of the world are different. Both the cultures are different in term of social, economic and political aspects (Bomhoff \& $\mathrm{Gu}, 2012)$. However, there are many values which are consistent between both the cultures. Modernity on the other hand, it linked to Western cultural values and culture. In other words, adoption of Western culture by Eastern part of the world is modernity (Basit, 2017; Jensen, Arnett \& McKenzie, 2011).

Here, it is pertinent to explain the difference between both the cultures and cultural values of Eastern and Western part of the world. In Eastern part of the world, people most of the time focus on group and group dynamics. On the other hand, in Western culture, the focus is upon individual and his/her desires (Triandis, 2018). This implies that Eastern cultural values are more oriented towards family and religion etc. On the other hand, in Western culture, values are more about individual autonomy (Lesthaeghe, 2014). People are more concerned in West about personal freedom and autonomy and they talk about personal accomplishments. However, in east, personal accomplishment is only valued when it is linked the wishes and desires of groups (Kagitcibasi, 2017).

Beside the adoption of Western family thought and family obligations, people are also adopting Western culture in term of food consumption. There are many researchers which suggested that young generation is consuming fast food as the sign of modernity (Mak, Lumbers \& Eves, 2012). Those who consume fast food look down at those who did not consume fast food and or not aware about fast food. Consumption of fast food started after the interaction of Eastern part of the world with Western part of the world (Chytkova, 2011). There are numbers of fast food chains and outlets which are operating even in underdeveloped and developing countries and offering discount on processed food (Mak, Lumbers \& Eves, 2012). 
There is also a change in the pattern of living and deciding residence among people. In most of the cases young educated adults are now considering urban residence and they are found less concerned about their rural background and rural attachments (Petrin, Schafft \& Meece, 2014). This modern value is actually accelerating internal emigration of the people from rural areas to urban areas. Urbanization is on the other hand, giving birth to new cultural values i.e. more importance to ascribed status and less importance to in born qualities of individuals (Petrin et al. 2011).

In Western culture, individual are credited on what they have done and what they have achieved. On the other hand, in Eastern culture, family background, cast and tribe still hold importance (Hebdige, 2012). Modern Western dressing values are also hitting Eastern values. It is found in literature that people more often educated people from universities focus very much on their dressing styles. Wearing suits (three piece pant coat) and even jeans and shirts are not the customs of Eastern part of the society (Stone \& Farnan, 2018).

Western cultural attributes and they are less concerned about traditional values and customs. Modernity is changing each and every aspect of the society from family to marriage, from education to job market, from dressing to professions and from food to constructing as well.

\section{Material and Methods}

The present research is conducted in two public sector universities i.e. University of Agriculture, Faisalabad and University of the Punjab, Lahore. Two different research sites are selected for the sake of making comparison of modernity on changing cultural patterns. Initially, researcher used quantitative researcher approach and conducted survey among the students using cross sectional survey design. Two stage probability sampling technique was used and a total of 420 students were selected using stratified sampling technique and simple random sampling technique respectively. Data was collecting using slightly modified standard tool of data collection.

Table No1

Percentage distribution of the respondents' institutions

\begin{tabular}{ccc}
\hline Respondents' program & Frequency & Percentage \\
\hline Punjab University & 209 & 50.9 \\
\hline Agriculture University & 136 & 33.1 \\
\hline Other & 66 & 16.1 \\
\hline Total & 411 & 100.0 \\
\hline
\end{tabular}

The respondents who were enrolled in public sector universities are included into Punjab University and Agriculture University. About $50 \%$ of the respondent reported that they are enrolled in Punjab University and 33.1\% of the respondents 
reported that they are enrolled in Agriculture University. On the other hand, about $16.1 \%$ of the respondents were enrolled in other university. It means that the sample of the present study is consistent with the distribution of the students in the sample.

\section{Results and Discussion}

Table No 2

Impression of western culture on lives

\begin{tabular}{ccc}
\hline Impact & Frequency & Percentage \\
\hline Strongly disagree & 46 & 11.2 \\
\hline Disagree & 80 & 19.5 \\
\hline Agree & 188 & 45.7 \\
\hline Strongly agree & 97 & 23.6 \\
\hline Strongly disagree & 35 & 8.5 \\
\hline Disagree & 38 & 9.2 \\
\hline Agree & 139 & 33.8 \\
\hline Strongly agree & 199 & 48.4 \\
\hline Total & 411 & 100.0
\end{tabular}

The results indicated that western culture had strong impression on the lives of students. About $11.2 \%$ of the respondents were strongly disagree, $19.5 \%$ were disagree, $45.7 \%$ were agree and $23.6 \%$ were strongly agree that there is strong impression of western culture on our lives. About $8.5 \%$ of the respondents were strongly disagree, $9.2 \%$ were disagree, $33.8 \%$ were agree and $48.8 \%$ were strongly agree with the statement. It means that respondents were of the views that the change in clothes, food and education is because of the westernization and modernization. However, the majority of the respondents were of the views that the westernization and modernization is gradually changing our cultural patterns i.e. $81 \%$ of sample were agree with statement that modernization and westernization is changing our cultural patterns (Abebe, 2007; Ballengee-Morris and Stuhr, 2001).

Table No 3

Percentage distribution of wearing western clothes as a status symbol

\begin{tabular}{ccc}
\hline Western dressing & Frequency & Percentage \\
\hline Strongly disagree & 47 & 11.4 \\
\hline Disagree & 101 & 24.6 \\
\hline Agree & 205 & 49.9 \\
\hline Strongly agree & 57 & 13.9 \\
\hline Total & 410 & 99.8
\end{tabular}

The results indicated that the majority of the respondents claim that they consider western clothes (pants, shirts) as a status symbol and they spend more money on them. Results indicated that about $11.4 \%$ of the students were strongly disagree, $24.6 \%$ were disagree, $49.9 \%$ were agree and $13.9 \%$ were strongly agree that 
they consider western clothes (pants, shirts) as a status symbol and they spend more money on them. Therefore, it is clear that being westernization is actually being modern and being well dress and it is actually a status symbol (Cook, 2005).

Table No 4

Association between modernity and changing culture

\begin{tabular}{|c|c|c|c|}
\hline \multicolumn{4}{|c|}{$\mathrm{H}_{1}$ : Higher the level of stay in university higher will be the level of modernity } \\
\hline \multirow{2}{*}{$\begin{array}{c}\text { Stay in } \\
\text { university }\end{array}$} & \multicolumn{3}{|c|}{ Modernity } \\
\hline & Lower & Medium & Higher \\
\hline 1st year & $8.0 \%$ & $12.2 \%$ & $16.0 \%$ \\
\hline 2nd year & $4.0 \%$ & $19.0 \%$ & $26.0 \%$ \\
\hline 3rd year & $36.0 \%$ & $21.0 \%$ & $20.4 \%$ \\
\hline 4 th year & $52.0 \%$ & $47.8 \%$ & $37.6 \%$ \\
\hline Total & $100 \%$ & $100 \%$ & $100 \%$ \\
\hline $\mathrm{X}^{2}=12.83$ & $\mathrm{df}=6$ & Sig. $=.046$ & \\
\hline \multicolumn{4}{|c|}{$\mathrm{H}_{2}$ : Cultural change is higher among urban students as compared to rural student } \\
\hline \multirow{2}{*}{ Area } & \multicolumn{3}{|c|}{ Cultural change } \\
\hline & Lower & Medium & Higher \\
\hline Urban & $42.9 \%$ & $58.1 \%$ & $59.4 \%$ \\
\hline Rural & $57.1 \%$ & $41.9 \%$ & $40.6 \%$ \\
\hline Total & $100 \%$ & $100 \%$ & $100 \%$ \\
\hline$X^{2}=7.38$ & $\mathrm{df}=2$ & Sig. $=.025$ & \\
\hline
\end{tabular}

These results also indicated that the majority of the urban students reported higher cultural change $(59.4 \%)$ and the majority of the rural students reported lower cultural change. In addition, both the area of residence and cultural change were found associated at $95 \%$ confidence interval ( $p$-value $<5 \%$ ).It is also confirmed from the results that urban areas of hubs of modernity which ultimately lead to cultural change (Shenassa et al. 2006).

\section{Conclusion}

The present study is aimed to find out the relationship between modernity and cultural change among the students studying in two public sector universities in Punjab, Pakistan. In addition, the study also finds out the moderating effect of global mindedness between the relationship of modernity and cultural change. Globalization lead modernity and western culture had very strong impression on the lives of the people and this strong impression is higher in urban areas as compared to the rural areas. Westernization and its linked concept of modernity are gradually changing Pakistani culture to western culture and more and more western values are now penetrating in Pakistani society. 


\section{Recommendations}

Though the contributions of the study are enormous therefore researcher enlisted some recommendations based on the empirical findings of the study. Because of rapidly penetrating modernity and western values which are devaluing local culture, therefore, special need is required to filter the beneficial and nonbeneficial values to protect indigenous culture. Modernity is also changing nonmaterial culture as well. People are now individualistic and think about themselves and less about their group. Therefore, collective vales also need to be promoted which enhance group solidarity. 


\section{References}

Abebe, T. (2007). Changing livelihoods, changing childhoods: patterns of children's work in rural southern Ethiopia. Children's geographies, 5(1-2), 77-93.

Amin, S. (2014). Capitalism in the age of globalization: The management of contemporary society. Zed Books Ltd.

Ballengee-Morris, C., \&Stuhr, P. L. (2001).Multicultural art and visual cultural education in a changing world. Art Education, 54(4), 6-13.

Bashkow, I. (2017). The meaning of whitemen: race and modernity in the Orokaiva cultural world. University of Chicago Press.

Basit, T. N. (2017). Eastern values; Western milieu: Identities and aspirations of adolescent British Muslim girls. Routledge.

Beck, U. (2018). What is globalization?.John Wiley \& Sons.

Belk, R. (2017). Collective Narcissism, Anti-Globalism, Brexit, Trump, and the Chinese Juggernaut, Markets, Globalization \& Development Review: Vol. 2: No. 3, Article 2. DOI: 10.23860/MGDR-2017-02-03-02

Bomhoff, E. J., \&Gu, M. M. L. (2012). East Asia remains different: A comment on the index of "self-expression values," by Inglehart and Welzel. Journal of CrossCultural Psychology, 43(3), 373-383.

Charron, N. (2016). Diverging cohesion? Globalisation, state capacity and regional inequalities within and across European countries. European Urban and Regional Studies, 23(3), 355-373.

Cook, N. (2005). What to wear, what to wear?: Western women and imperialism in Gilgit, Pakistan. Qualitative Sociology, 28(4), 351-369.

Childs, P. (2016). Modernism. Routledge.

Chytkova, Z. (2011). Consumer acculturation, gender, and food: Romanian women in Italy between tradition and modernity. Consumption Markets $\mathcal{E}$ Culture, 14(3), 267-291.

Feola, G. (2015). Societal transformation in response to global environmental change: a review of emerging concepts. Ambio, 44(5), 376-390.

Godart, F., Maddux, W. W., Shipilov, A., \&Galinsky, A. D. (2015). Fashion with a foreign flair: Professional experiences abroad facilitate the creative innovations of organizations. Academy of Management Journal, 58(1), 195220.https://doi.org/10.5465/amj.2012.0575 
Gray, B., \& Purdy, J. (2018).Collaborating for our future: Multistakeholder partnerships for solving complex problems. Oxford, UK: Oxford University Press. https://doi.org/10.1093/oso/9780198782841.001.0001

Hebdige, D. (2012). Subculture: The meaning of style. Routledge.

Hong, Y., \&Cheon, B. K. (2017). How does culture matter in the face of globalization? Perspectives on Psychological Science, 12, 810-823. https://doi.org/10.1177/1745691617700496

Jensen, L. A., Arnett, J. J., \& McKenzie, J. (2011).Globalization and cultural identity.In Handbook of identity theory and research (pp. 285-301).Springer, New York, NY.

Kagitcibasi, C. (2017). Family, self, and human development across cultures: Theory and applications. Routledge.

Lesthaeghe, R. (2014). The second demographic transition: A concise overview of its development. Proceedings of the National Academy of Sciences, 111(51), 18112-18115.

LeVine, R. A., \& White, M. I. (2017). Human conditions: The cultural basis of educational developments. Routledge.

Mak, A. H., Lumbers, M., \& Eves, A. (2012). Globalisation and food consumption in tourism. Annals of tourism research,39(1), 171-196.Markets, Globalization, and Development Review, Vol. 2 No. 3, pp. 1-8.

Mignolo, W. (2011). The darker side of western modernity: Global futures, decolonial options. Duke University Press.

Orzeata, M. (2013).The Impact of Globalization on Interpersonal and CrossCommunitarian Communication.International Journal of Communication Research, 3(3).

Persson, R. S. (2012). Cultural variation and dominance in a globalised knowledgeeconomy: Towards a culture-sensitive research paradigm in the science of giftedness. Gifted and talented International, 27(1), 15-48.

Petrin, R. A., Farmer, T. W., Meece, J. L., \&Byun, S. Y. (2011).Interpersonal competence configurations, attachment to community, and residential aspirations of rural adolescents. Journal of youth and adolescence, 40(9), 1091-1105.

Petrin, R. A., Schafft, K. A., \&Meece, J. L. (2014). Educational sorting and residential aspirations among rural high school students: What are the contributions of schools and educators to rural brain drain? American Educational Research Journal, 51(2), 294-326. 
Stone, E., \&Farnan, S. A. (2018). The dynamics of fashion.Bloomsbury Publishing USA.

Shenassa, E. D., Liebhaber, A., \&Ezeamama, A. (2006). Perceived safety of area of residence and exercise: a pan-European study. American journal of epidemiology, 163(11), 1012-1017.

Shakeel, A.(2018).Assistant Country Director and Chief of the Development Policy Unit, UNDP Pakistan.

Tenhunen, S. (2018).A Village Goes Mobile: Telephony, Mediation, and Social Change in Rural India, Oxford University Press, Oxford.

Triandis, H. C. (2018). Individualism and collectivism. Routledge. 